\title{
The Effect of Dividends and Earnings per Share on the Stock Market Value by Moderating Bank Size
}

\author{
Sanaa Maswadeh \\ Middle East University, Amman, Jordan \\ Thaer Ahmad Abutaber, Mustafa Saeed Alathamneh \\ Jadara Private University, Amman, Jordan
}

\begin{abstract}
The aim of this study was to investigate the effect of dividend distributions and earnings per share by moderating bank size as measured by its total assets on the stock market value of banks operating in Jordan during the period between 2011 and 2016. The hypotheses of the study were tested based on multiple and hierarchical regression method. The most important result of the study is that the earnings per share is the strongest variable that helps in predicting the stock market value of the bank shares, in addition to the significant effect of bank size as measured by its total assets.
\end{abstract}

Keywords: dividend, earnings per share, stock market value, bank’s size, banks operating in Jordan

\section{Introduction}

The dividend distribution policy is an important financing policy in banks because of its direct relationship to shareholders and its reflection of the share price in the market. The dividend policy is the approach adopted by banks in determining the part of the profits to be distributed to the owners and the part that is being held.

In reference to literature, accounting thought and the practical reality of companies, the decision to distribute profits forms important decisions related to the policies of the company. This also affects their investment decisions and their ability to achieve future returns which are necessary factors for the survival, sustainability, and increased competitiveness of the companies at the local and international levels. Complementarily, companies can make the decision to retain profits and not to distribute them in the form of retained earnings. However, the holding of profits will lead to fluctuation of profit distribution from year to year. Accordingly, the instability in the policy of profit distribution, which would be reflected on a large segment of investors in the financial market who rely on dividends distribution as a basis for investment in shares, could reflect negatively the prices of banking shares in the financial market. Hence, this study was conducted to examine the effect of dividend distributions and earnings per share by moderating bank size as measured by its total assets on the stock market value of banks operating in Jordan.

\footnotetext{
Acknowledgment: Sanaa Maswadeh is grateful to the Middle East University, Amman, Jordan for all support provided to publish research article. Also Thaer Abutaber, and Mustafa Alathamneh are grateful to Jadara Private University, Irbid, Jordan.

Sanaa Maswadeh, professor, Accounting Department, Middle East University. Amman, Jordan.

Thaer Ahmad Abutaber, associate professor, Accounting Department, Jadara Private University. Amman, Jordan.

Mustafa Saeed Alathamneh, assistant professor, Accounting Department, Jadara Private University. Amman, Jordan.
} 


\section{Significance of the Study}

The study is significant as it sought to examine in depth the effect of both dividends and earnings per share on the stock market value of banks operating in Jordan in light of differences of the size of the bank, and the consequent assistance of the administration in making decisions that improve the market value of their shares, which subsequently would stimulate shareholders and attract investors to invest in the banks' shares. The success of banks in maintaining shareholders and attracting new investors improves the investment climate in the financial markets by setting the conditions for attracting investments. The importance of this study is also exemplified in the possibility of reaching several recommendations in light of the results of the study, which can be utilized for future research.

\section{Problems of the Study}

According to stock pricing models, the stock price in a market is influenced by the management's dividend policy. On the other hand, banks' growth rate is directly affected by the amount of returned earnings being held and reinvested that affect the returns and growth rate of shares. So, in the case of holding more profits, this increases the rate of growth, while reducing the retained earnings as a result of the increase in the amount of dividends distributed leading to reduced growth rate which in turn expected to reflect negatively in the earnings per share. As the goal of the bank is to maximize the wealth of shareholders by reaching the highest possible share price, the achievement of that objective therefore requires decision-making and selection of policies that have a positive effect on the share price in the market. Hence, this study sought to answer the following main question: What is the effect of dividends and earnings per share by moderating bank size on the market value of shares of banks operating in Jordan during the period between 2011 and $2016 ?$

\section{Hypotheses of the Study}

Hypotheses of the study were established based on the literature and logic of accounting, which states that increasing the funds invested in the assets of the company (bank size) will increase the ability of the bank to achieve profits and return them. This is expected to lead to an increase in shares returns and dividends which is supposed to reflect positively the value of the bank, by increasing its ability to attract investors and their ability to retain and buy shares, and accordingly, reflect positively the stock market value.

Therefore, the following hypotheses were tested in this study:

(1) There is no significant effect of the dividends on the stock market value of the banks operating in Jordan;

(2) There is no significant effect of the earnings per share on the stock market value of the banks operating in Jordan;

(3) There is no significant difference in the dividends and earnings per share on the stock market value moderated by the size of the banks operating in Jordan.

The hypotheses of the study can be illustrated by Figure 1.

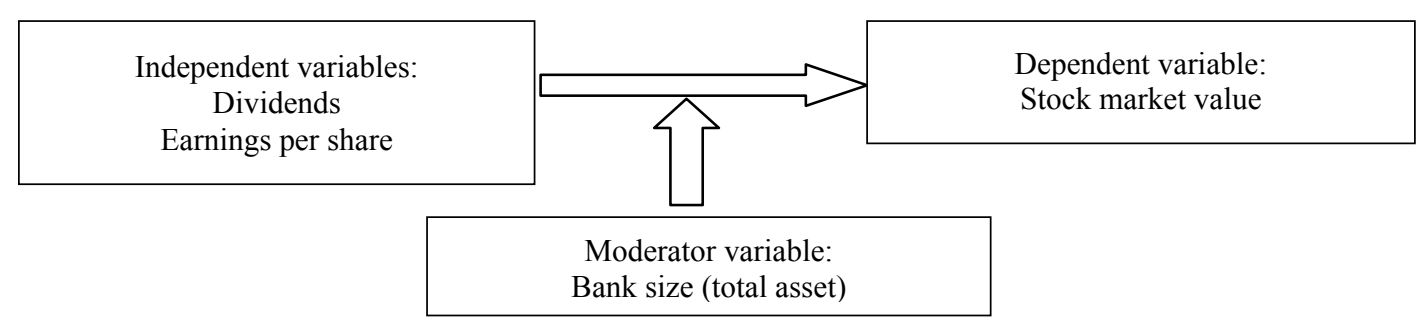

Figure 1. Study model. 


\section{Contribution of the Study}

This research contributes to the study of the effect of the earnings per share and dividends, which managers depend on as information or signals theory, which is connected to the market reflected in the trading behavior of investors and shareholders, and which in turn affects the activation of the financial market and increases its effectiveness. The study also contributes to a better understanding about the effect of earnings per share and dividends on the stock market value of banks operating in Jordan in light of the size of the banks as measured by its total assets. The study also tries to reach conclusions and recommendations that would assist the management of the Jordanian banking sector in making decisions regarding the differentiation between distributing profits and returning them, where such decisions would affect the banks' ability to retain existing shareholders and attract new shareholders. Consequently, these decisions will also affect the banks' stock value, viability, and competitiveness, both domestically and globally.

\section{Theoretical Framework and Literature Review}

Dividends are defined as "a part of the profits that the Board of Directors distributes to shareholders after approval by the General Assembly in cash or other tangible asset" (Kieso, Weygandt, \& Warfield, 2014, p. 776). In the opinion of Zarkoun (2010, p. 89), dividend policy reflects "the substance of the decision to distribute dividends or retained for reinvestment in the company". Subramanyam and Wild (2014) defined earnings per share as a share of earnings after deducting preferred dividends. Cohen, Holder-Webb, Nath, and Wood (2012) stated that the stock market value of shares represents the prevailing share price in the financial market, reflecting the price paid by investors as the price of the company's assets, which measures the actual price of the shares traded at the end of the year. It should be mentioned that when choosing a particular dividend type or policy, the company must consider two main objectives: The first is to provide sufficient funds to pay dividends and the second is to maximize the bank shareholders' wealth (Brish \& Badarouni, 2013). The banks' dividend policies vary according to what shareholders and investors want, with each type of dividend policy having its own timing characteristics and the ability to convert it into liquidity. It should be noted that there is a set of theories used in the choice of dividend policy dealing with the relationship between the amount of profit distributed on the one hand, and the stock market price and return on investment on the other hand. And the theory of Ross (1977) on information content or signaling in which dividends can be interpreted as a signal to shareholders and investors about the company's future profit indexes, whereby Ross (1977) asserted that the increase in dividend is seen as a positive sign, and conversely, the decline in dividend is seen as a negative sign.

$\mathrm{He}, \mathrm{Li}$, Shi, and Twite (2015) believed that if dividends fall, this would give investors and traders in the financial market a negative impression of weakness in the company's performance, which could lead to a decline in the stock market value. Sharb (2006) concluded that investors view dividends as a source of information about the company. This signifies that investors see the dividend policy as an indicator of the company's success. Thus, the increase in the value of dividend distributed per share from one year to another leaves a positive impression among the financial market traders about the effectiveness of the company's performance, leading to a higher stock market value. Gee-Jung (2017) noted that earnings per share has a significant positive effect on the value of the company's shares in the financial market because of the dynamic information in the financial statements and the speed of impression that it leaves on the users. Hanafi (2003) believed that increasing the company's ability to achieve returns leads to increased dividends, and subsequently, 
the increase in dividends may be greater than the increase in profits. The investors may prefer the company to re-invest dividends, so that this may be positively reflected on the value of their market shares. Sadr, Rostami, and Vadiee (2017) found that the more companies distributed more dividends, the more positive it was on the value of their market shares, and thus, on the company's ability to increase sources of their financing. D'Souza, Srichanachaichok, Wang, and Yao (2016) concluded that if the company is able to maintain normal distribution of the average earnings per share, particularly in the case of efficient financial market hypothesis, this would be the best situation for large companies as it would be able to reflect the value of their stocks in the financial market. Al-Twaijry (2006) studied the correlation between dividends and profits with share market value and their returns. He found that there is a strong correlation between the price of ordinary shares and dividends. A dividend is the strongest variable that helps predict the market's stock value. In contrast, the strongest variable to predict changes in stock market price is changes in stock returns. In the study by Kothari and Shanken (1992) which examined the effects of both dividend growth and investment growth on the expected future returns, it was found that both dividends and expected future returns explained $90 \%$ of the change in stock returns. The study of Dasilas, Lyroudi, and Ginoglou (2008) which aimed to test the effect of the announcement of profits and dividends on the market value of shares and trading volume in the Greek financial market found a positive correlation between the market value of the stock and the volume of trading as a result of the announcement of dividends. In their study, on a sample of companies in Ghana's financial market, Asamoah and Nkurmah (2010) concluded that the announcement of dividend distribution significantly affected the market value of the stock, especially if the financial market was efficient. Yang and $\mathrm{Wu}$ (2015), in their study, aimed to test the effect of the announcement of dividends before and after 10 days of loss of right to obtain dividend on the market value of the shares on the Taiwan Stock Exchange. They found a significant increase in the market value of the stock within the 10 days preceding the date of loss of right to obtain dividends compared to 10 days following the date of loss of right to obtain dividends. Benamoun and El-Sherif (1990) studied the strength and direction of the correlation between dividends, retained earnings per share, and stock value. He concluded that the correlation between dividends and share market value is greater than the correlation between retained earnings per share and stock market value.

The study by Abu Al-Qasim (2005) dealt with the effect of dividends on the stock market value of the Khartoum Stock Exchange which is considered a new market where there is not enough circulation to raise share market price and achieve capital gains, thus significantly affecting investor decision. He concluded that the Sudanese investors make their decision in light of the dividends received which is considered as returns to the investors. Therefore, the investors compared between the proceeds of deposits in the banks and dividends where they tend to invest in higher returns.

\section{Research Methodology}

The study was conducted on a population which comprised the financial statements of all banks operating in Jordan and listed on the Amman Stock Exchange. The total number of banks was 16 banks until the end of 2016 and all of population was selected to test the hypotheses of the study. The number of observations related with each study variable was 96 observations (16 banks $\times$ six years between 2011 and 2016), which were collected from the financial reports of Jordanian banks issued by the Jordan Securities Commission. 


\section{Empirical Results}

SPSS Version 22 was used to examine the data, test the hypotheses, and model the data which included both time-series data and cross-section data. The researcher modeled the study in the form of regression equations to link the independent and dependent variables by moderating the size of the bank's assets, as described in the following:

$$
\begin{gathered}
S m v_{i t}=\alpha_{0}+\beta_{1} \operatorname{Div}_{i t}+\beta_{2} E P S_{i t}+\varepsilon_{i t} \\
S p_{i t}=\alpha_{0}+\beta_{1} \operatorname{Div}_{i t}+\beta_{2} E P S_{i t}+\beta_{3} \operatorname{Size}_{i t}+\varepsilon_{i t}
\end{gathered}
$$

where:

Dependent variable: $\operatorname{Smv}$ (stock market value);

Independent variables: Div (dividend), EPS (earnings per share);

Moderator variable: Bank size (natural log of total asset).

Table 1 shows the results of the test on the relevance of the study data to the assumptions of regression analysis.

Referring to Table 1 and based on the Central Limit Theory which states that the normal distribution condition of large samples $(n>30)$ can be assumed, the data can therefore be assumed to be normally distributed, since the number of observations in the study is 96 (Johnson, 2004). In addition, Table 1 shows no multicollinearity between the independent variables, where the value of variance inflation factor (VIF) is less than 10 for each independent variable. Thus, it is clear that there is no multicollinearity between the independent variables of the study, and therefore, the level of variance in each independent variable of study is accepted in Models 1 and 2 of the study. Autocorrelation between standard error of the estimate limits in the regression model was tested based on the Durbin-Watson (D-W) test. Table 1 shows that the D-W test value was limited to $0-4$ and this indicates that the study data are free from the problem of autocorrelation.

Table 1

Relevance of Study Data to Regression Analysis

\begin{tabular}{lcc}
\hline Variables & Model 1 & Model 2 \\
\hline VIF-Dividends & 4.354 & 5.753 \\
VIF-EPS & 4.354 & 6.425 \\
VIF-Size & & 7.459 \\
D-W test & 1.801 & 1.812 \\
ch $^{2}$ & 3.52 & 5.99 \\
Sig. $\left(\mathrm{ch}^{2}\right)$ & 0.36 & 0.27 \\
No. of observations & 96 & 96 \\
\hline
\end{tabular}

The ordinary least square (OLS) model was used in addition to adoption of fixed effect and random effect to choose the appropriate models for the study. The Hausman test was used to decide whether fixed or random effects model would be more appropriate. Since $c h^{2}$ was greater than $5 \%$ in Models 1 and 2, the random effect of the regression model should be used.

Table 2 shows the results of the hypotheses tested in this study. 
Table 2

The Moderating Effect of Bank Size on Stock Price

\begin{tabular}{lcc}
\hline Variables & Model 1 & Model 2 \\
\hline Constant & -0.919 & -32.051 \\
Dividends & 0.073 & 0.025 \\
EPS & 0.755 & 0.52 \\
Size & & 0.372 \\
$F$-Sig. & $0.00^{* * *}$ & $0.00^{* * *}$ \\
Sig.-Div & 0.281 & 0.691 \\
Sig.-EPS & $0.00^{* * *}$ & $0.00^{* * *}$ \\
Sig.-Size & & $0.00^{* * *}$ \\
$R^{2}$ & 0.602 & 0.677 \\
Adjusted $R^{2}$ & 0.593 & 0.666 \\
Sig. $(F)$ & $0.00^{* * *}$ & $0.00^{* * *}$ \\
No. of observations & 96 & 96 \\
\hline Notes ${ }^{*}:$ Significant at the 0.1 level; ${ }^{* *}:$ Significant at the 0.05 level; and ${ }^{* * * *}:$ Significant at the 0.01 level.
\end{tabular}

Notes. ": Significant at the 0.1 level; " : Significant at the 0.05 level; and "*: : Significant at the 0.01 level.

Based on the hierarchical multiple regression model used to test the effect of the independent variables on the dependent variable in the existence of the moderator variable (bank size), Table 2 shows that Model 1 obtains a coefficient value of $R^{2}=0.602$, indicating the dividends and the earnings per share explained $60.2 \%$ of the change in the stock market value of the banks. The significant value of the dividends (Sig. $=0.281$ ) in Model 1 confirms that there is no significant effect of the dividends in the share market value at a significant level $(\alpha \leq 5 \%)$. Thus, the alternative hypothesis was rejected and the null hypothesis which states that "There is no significant effect of the dividends on the stock market value of the banks operating in Jordan" was accepted.

This finding is in agreement with the outcomes of the study by Akbar and Stark (2003), in which they concluded that there was no significant correlation between dividends and stock market value. In contrast, this finding is incongruent with the results of the studies by Dasilas et al. (2008), Sadr et al. (2017), Asamoah and Nkurmah (2010), and Al-Twaijry (2006), which all found that dividends significantly affect the stock market value.

Table 2 shows that the significant value of the earnings per share was Sig. $=0.00$, which confirms the existence of the effect of the earnings per share on the stock market at a significant level $(\alpha \leq 5 \%)$. Accordingly, the alternative hypothesis which states that "There is a significant effect of the earnings per share on the stock market value of the banks operating in Jordan" was therefore accepted. This result is consistent with the outcomes of the studies by D'Souza et al. (2016), Gee-Jung (2017), and Al-Twaijry (2006), in which earnings per share was found to be significant and had a positive effect on the stock market value.

The results of Table 2 and the reference to Model 2 indicate that the value of the explanation coefficient was $R^{2}=0.677$. This means that dividends and earnings per share moderated by the size of the banks' assets explained $67.7 \%$ of the variances of the banks' stock market value, and there was an increase in the explanation coefficient $R^{2}$ value at $7.5 \%$ compared to Model 1. In addition, results in Table 2 show that the significance value of the dividends was Sig. $=0.691$, while the significance value of the earnings per share was Sig. $=0.00$ and the significance value of bank size as the moderating variable was Sig. $=0.00$. These results confirm that 
there was no significant effect of the dividends, put the significant effect of earnings per share and the size of the banks' assets on the stock market value at the level $(\alpha \leq 5 \%)$. Accordingly, the alternative hypothesis stating that "There is significant difference in the effect of dividends and earnings per share on the stock market value moderated by the size of the banks operating in Jordan" was accepted. This finding is in agreement with the results of the studies by Nodeh, Anuar, Ramakrishnan, and Raftnia (2016), Hamdan and Al-Qada (2013), and Abu Zaiter (2006), which found a significant and positive effect of the size of the bank as measured by its total assets in financial performance of the banks.

\section{Conclusion}

The results of the statistical analysis of the study data, which examined the effect of dividends and earnings per share on the stock market value of banks operating in Jordan, showed that the dividends and earnings per share when considering bank size as the moderator variable explained $67.7 \%$ of the variance of the stock market value. It was found that earnings per share is the strongest variable that helps to predict the market value of the banks' shares, while there was no significant effect of the dividends in the prediction of the banks' stock market value. Additionally, bank size was found to have a significant effect on the prediction of stock market value. Thus, these results emphasize the significance of information related to earnings per share and the rapid impression and effect that the users of the financial statements have on market value of the banks' shares. It is an indication that bank size is important in expressing the market share of the banks in the financial market, where increasing the size of the banks leads to the availability of more investment opportunities that can be used to generate profits, which in turn is reflected on the earnings per share. The researchers recommend that the attention of the banks' management is focused on choosing a dividend policy that distinguishes between the banks distributing a portion of the profits to the shareholders and returning the current profits to be invested in new investment opportunities. Allocating a portion of the profits to the shareholders would motivate and attract them to invest in the banks' shares. Accordingly, returning the current profits for new investment opportunities would support the banks' ability to continue and grow and achieve higher levels of profit. This would reflect positively on the earnings per share which has been proven in this study to be an important variable influencing the stock market value of the banks operating in Jordan.

\section{References}

Abu Al-Qasim, M. (2005). The effect of the dividends on the stock market price (Unpublished master thesis, Soudan University for Science and Technology, Soudan).

Abu Zaiter, H. (2006). The profitability of commercial banks operating in Palestine (Unpublished master thesis, Islamic University of Gaza, Palestine).

Akbar, S., \& Stark, A. W. (2003). Deflators, net shareholder cash flows, dividends, capital contributions and estimated models of corporate valuation. Journal of Business Finance and Accounting, 30(9-10), 1211-1233.

Al-Twaijry, A. (2006). An analysis of the relationships among stock prices (and returns), dividends and earnings in the UK stock market. Journal of King Saud University, 18(2), 63-91.

Asamoah, G., \& Nkurmah, K. (2010). The impact of dividend announcement on share price behavior in Ghana. Journal of Business \& Economics Research, 8(4), 47-58.

Benamoun, H., \& El-Sherif. (1990). Dividend distribution policies and its effect on share price in Jordanian industrial companies (Unpublished master thesis, University of Jordan, Jordan).

Brish, A., \& Badarouni, I. (2013). Determinants of dividends in private Algerian institutions. Journal of Researcher, Academy for Social and Human Studies, 10, 13-26.

Cohen, J. R., Holder-Webb, L. L., Nath, L., \& Wood, D. (2012). Corporate reporting of nonfinancial leading indicators of 
economic performance and sustainability. Accounting Horizons, 26(1), 65-90.

D’Souza, I., Srichanachaichok, V., Wang, G. J., \& Yao, Y. Q. (2016). The enduring effect of time-series momentum on stock returns over nearly 100 years. Paper presented at The Asian Finance Association Annual Meeting (Asian FA), Thailand.

Dasilas, A., Lyroudi, K., \& Ginoglou, D. (2008). Joint effects of interim dividend and earnings announcements in Greece. Studies in Economics and Finance, 25(4), 212-232.

Gee-Jung, K. (2017). Valuation role of accounting information in profit and loss firms. International Business and Management, 14(1), 15-24.

Hamdan, N., \& Al-Qada, A. (2013). Affect of capital structure on the performance of Jordanian banks listed on the Amman Stock Exchange: Analytical study. Al-Manarah Journal, 19(4), 159-186.

Hanafi, A. G. (2003). Stock exchange. Alexandria, Egypt: Daurr Aljamieh Publishing.

He, X., Li, M. S., Shi, J., \& Twite, G. (2015). Why do firms pays stock dividendes: Is it just a stock split? Australien Journal of Management, 41(3), 508-537.

Johnson, O. T. (2004). Information theory and the central limit theorem (1st ed.). London: World Scientific.

Jordan Securities Commission. (n.d.). Amman Stock Exchange. Retrieved from http://www.ase.com.jo/

Kieso, D. E., Weygandt, J. J., \& Warfield, T. D. (2014). Intermediate accounting (15th ed.). New York, NY: John Wiley \& Sons.

Kothari, S. P., \& Shanken, J. (1992). Stock return variation and expected dividends: A time-series and cross-sectional analysis. Journal of Financial Economics, 31(2), 177-210.

Nodeh, F. M., Anuar, M. A., Ramakrishnan, S., \& Raftnia, A. A. (2016). The effect of board structure on banks financial performance by moderating firm size. Mediterranean Journal of Social Sciences, 7(1), 258-263.

Ross, S. (1977). The determination of financial structure: The incentive-signaling approach. Bell Journal of Economics, 8(1), 23-40.

Sadr, S. A., Rostami, A. A. A., \& Vadiee, M. H. (2017). Studying firms' stock liquidity over firms life cycle: An empirical evidence from Iranian stock market. The IIOAB Journal, 8(1), 35-41.

Sharb, O. (2006). The effect of the announcement of the dividend on the shares price of listed companies in Palestine Stock Exchange Securities: An empirical study (Unpublished master thesis, Islamic University of Gaza).

Subramanyam, K. R., \& Wild, J. J. (2014). Financial statement analysis (11th ed.). Boston, MA: McGraw-Hill Irwin.

Yang, J. J., \& Wu, T. H. (2015). Announcement effect of cash dividend changes around ex-dividend days: Evidence from Taiwan. The International Journal of Business and Finance Research, 9(2), 77-89.

Zarkoun, M. (2010). The impact of the public subscription on the dividends policy in economic institutions quoted in the stock exchange: A comparative analytical study of the Algiers Tasir Organization. Journal of Research, University of Ouargla, 8 , 85-99. 